\title{
Exemplary History: Competition in Roman Historiography
}

\section{História exemplar: a Competiçāo na Historiografia Romana}

\author{
Catalina Balmaceda \\ https://orcid.org/0000-0001-8650-6421
}

\section{ABSTRACT}

A great part of the perceived value of history in the ancient world was connected with its educational function. In one way or another, it was regarded as a beneficial guide to conduct or as magistra vitae (Cicero, De Oratore II, 36). To give political instruction and advice on the one hand (Polybius, I, 1, 2), and to provide exempla, were two major aims of history. This paper will argue that by narrating the history of the past, historians not only judged past actions or people, and provided useful moral examples to their contemporaries, but also stimulated a type of competition between past and present times. By recording good examples to be imitated and bad ones to be avoided, the Roman historians promoted the code of values of the maiores for their own time, fostered action and, to a certain extent, became significant indicators to Roman society. This competitive aspect of Roman historiography is illustrated here in three distinct categories, analysing the work of major Roman historians: Sallust, Livy and Tacitus.

\section{KEYWORDS}

Roman historiography; Historia magistra vitae; Historians.

\section{RESUMO}

Uma grande parte do valor percebido da história no mundo antigo estava ligada à sua função educacional. De um modo ou de outro, ela foi considerada como um guia benéfico para a conduta ou como magistra vitae (CÍCERO, De Oratore II, 36). Dar instrução política e aconselhamento, por um lado (POLÍBIO, I, 1, 2), e fornecer exempla, por outro lado, eram os dois grandes objetivos da história. Este artigo argumentará que, ao narrar a história do passado, os historiadores não apenas julgavam ações ou pessoas do passado, e forneciam exemplos morais úteis a seus contemporâneos, mas também estimulavam um tipo de competição entre os tempos passado e presente. Ao registrar bons exemplos a serem imitados e maus a serem evitados, os historiadores romanos promoviam o código de valores dos maiores para seu próprio tempo, fomentavam a ação e, em certa medida, tornaram-se indicadores significativos para a sociedade romana. Esse aspecto competitivo da historiografia romana é ilustrado aqui em três categorias distintas, analisando o trabalho de grandes historiadores romanos: Salústio, Tito Lívio e Tácito.

\section{PALAVRAS-CHAVE}

Historiografia Romana; Historia magistra vitae; Historiadores. 
One of the main purposes of Roman historical writing was to learn something from the past. The narration of past events fulfilled a specific and practical part in the community, as Livy said:

There is this exceptionally beneficial and fruitful advantage to be derived from the study of the past, that you see set in the clear light of historical truth, examples of every possible type. From these you may select for yourself and your country what to imitate, and also what, as being mischievous in its conception and disastrous in its results, you are to avoid" [Hoc illud est praecipue in cognitione rerum salubre ac frugiferum, omnis te exempli documenta in inlustri posita monumento intueri; inde tibi tuaeque rei publicae quod imitere capias, inde foedum inceptu foedum exitu quod vites.] (Livy, praef. 10). ${ }^{1}$

By their narratives, the Roman historians, then, provided good models to imitate and bad ones to avoid. In one way or another, history was regarded as a beneficial guide to behaviour, or as Cicero would crisply summarise it, as magistra vitae (Cicero, De Oratore. II, 36).

Thus, the topics with which Roman history was concerned helped to promote the same kind of behavior that had been followed in the past, encouraging fidelity to the mores maiorum through exempla. (HÖLKESKAMP 2004, p. 169-98; WALTER 2004). The weight and authority that exemplarity had in Roman culture pervaded its society in a way that is difficult to assess in all its significance today. It worked as a complex process that assumed that past actions could be in some way inspirational to the present, or a model for future actions, as if the possibilities and values of the actors remained similar. ${ }^{2}$ As Matthew Roller said: "Exempla (...) constitute a form of moral discourse; and they evince a particular historical consciousness." (ROLLER 2018, p. 1).

This paper will focus on the competitive aspect of Roman historians and will show how by means of their historical narratives they aimed to foster action in their audiences. By narrating the history of their past, Roman historians provided a useful repertoire of examples to their contemporaries, and also

\section{1 - All translations are from the latest Löeb editions with minor modifications, unless otherwise indicated.}

2 - For exemplarity in Roman historiography, see esp. Chaplin 2000; Roller 2004; 2009; 2018. In a similar note, see Marincola 2010, $p$. 259-289. There is a vast bibliography on the relationship between rhetoric and ancient historiography, see for example, Wiseman 1979; Fornara 1983; Woodman 1984; Kraus; Woodman 1997; Marincola 2007. 
tried to stimulate action through competition between past and present times. Emulation was something that the exemplarity culture of the mores maiorum in Rome tended to promote and was emphasised by rhetorical education. ${ }^{3}$ These two elements, the culture of exemplarity and the specific stress in competitive action with the maiores, gave Roman historiography a particular hue which made history especially useful and practical.

\section{Internal competition}

I have identified at least three kinds of competition in Roman historical writing. The first one which I will refer to is the internal competition that concerns the actors that appear in the historical account. I have called it internal because both contenders - or group of contenders - are placed within the narrative and therefore the competition is self-contained or somehow encapsulated in the internal audience. ${ }^{4}$ Historical characters compete with one another in a time-frame set in the past, and this may be seen mainly through explicit comparisons or when the historians use the specific word certamen or the verb certo which means to contend for superiority. ${ }^{5}$ The republican historian, Sallust, for example, tells us how old Romans cultivated high moral standards in peace and in war; they lived in the greatest harmony and had little or no avarice (Sallust, Bellum Catilinae IX, 1-2). "To such men," says Sallust, "no toil was unusual, no place was difficult or inaccessible, no armed enemy was formidable; their valor had overcome everything [Igitur talibus viris non labor insolitus, non locus ullus asper aut arduus erat, non armatus hostis formidulosus: virtus omnia domuerat]" (Sallust, Bellum Catilinae VII, 5), because "citizens contended with citizens in nothing but virtue [cives cum civibus de virtute certabant]" (Sallust, Bellum Catilinae IX, 2, my emphasis). This is obviously an idealized image, but it is still significant that the historian chose to portray early Rome as a field where good men competed with one another in uprightness, and this competition, according to Sallust, was carried on throughout the centuries. One generation after another contended for moral excellence,
3 - For exempla originating in rhetorical education, see ROLLER 2018 passim, but esp. p. 11-13.

4 - For different types of audiences, see CHAPLIN 2000, p. 4, p. 50-53, p. 103.

5 - OLD, s.v. certo 1. For more on the language of competition and rivalry in literature, see WISEMAN 1979, p. 27-29; HARDIE 1993, p. 116-119. 
allowing the Roman Republic to show its glorious achievements along the way. It is only when the historian moves nearer to his own age, the first century $\mathrm{BC}$, that this idyllic picture is brutally shattered:

For after the tribunician power had been restored in the consulship of G. Pompey and M. Crassus (...) everybody, though affecting concern for the public good, contended every one for his own interest [Nam postquam Cn. Pompeio et M. Crasso consulibus tribunicia potestas restituta est (...) bonum publicum simulantes pro sua quisque potentia certabant] (Sallust, Bellum Catilinae XXXVIII, 1-4, my emphasis).

In these two cases of competition both group of rivals share the same historical time: on the one hand, a time in the past prior to the destruction of Carthage when according to Sallust Romans fought to excel in virtue, and on the other, a time closer to the historian, but still in the past, which he identifies with the restoration of the tribunician power under Crassus' and Pompey's consulship in $70 \mathrm{BC}$, when men changed the goals of their competition for the worse, as private interests seemed to be the main aim: pro sua potentia.

But there are more specific examples of internal competition in Sallust. Cato and Caesar, for instance, in the Bellum Catilinae are a pair competing to excel in virtus in a period where the representatives of Roman virtue, according to Sallust, were almost non-existent:

in many periods no one at all in Rome was outstanding for his virtus. But within my own memory there were two men of towering virtue, though of opposite character: M. Cato and C. Caesar [multis tempestatibus haud sane quisquam Romae virtute magnus fuit. Sed memoria mea ingenti virtute, divorsis moribus fuere viri duo, M. Cato et C. Caesar] (Sallust, Bellum Catilinae LIII, 6).

The details of this syncrisis are familiar to all and studies abound (BATSTONE 1988; SKLENÁR 1998; KAPUST 2011). Caesar was praised for his generosity and benefactions 
[munificentia ac beneficiis], Cato for the uprightness of his life [integritate vitae]; one was gentle and compassionate; the other possessed a dignified severity. The easy-going nature of Caesar was contrasted with Cato's steadfastness. The former wanted to show his virtus in a new war and longed for great power; the latter, on the contrary, cultivated self-control, propriety and above all austerity (Sallust, Bellum Catilinae LIV). Moreover, even Caesar's and Cato's speeches in the Bellum Catilinae contend with one another. Caesar's speech against putting the conspirators to death relies mainly on historical exempla and jurisprudence. As a plea for moderation, it proposes exile and not death. Cato, on the other hand, very dramatically favours capital punishment and supports severitas. Even though one can identify the winner in the historical senatorial debate Cato -, the information that Sallust gives in his account does not allow the reader to identify the winner of the contest in the narrative: the sense that the historian is presenting two competing models of being and behaving in the turmoil of the late Republic is evident.

A subtler and less explicit contest appears in the Bellum Iugurthinum where three successive Roman leaders strive to defeat the Numidian Jugurtha and win the definitive battle. Sallust's presentation of consecutive commanders, Metellus, Marius, and Sulla are there to show how difficult it was to achieve the goal and how each commander-in-chief excelled his predecessor in method and strategy. Neither Metellus' nor Marius' skills were able to bring the war to an end, but only Sulla's bargain with King Bocchus. It is striking that the Romans, who possessed good generals, soldiers, and weapons, were able to win the war only through treachery. In fact, they win by using the same deceitful techniques as Jugurtha had used before. The only difference was that the Romans used these skills - mainly deception and bribery - more effectively than the Numidian king. ${ }^{6}$ So here we have a double competition going on: one among the Roman commanders themselves succeeding and replacing one another, the last one trying to surpass the previous one; and the other contest is that 
between the barbarian and the Roman way of using dishonesty as a tactic for winning wars. Sallust denounces this ambiguous competition: Rome wins, but it is not a victory to be proud of.

In the same vein, Livy in his $A b$ Urbe Condita also gives the picture of characters competing with each other within his historical narrative framework. It was not only generals or statesmen who competed in valour or prudence - as we see when the author refers to old republican war heroes such as Fabius Maximus (22.18.8-9), Marcellus (38.43.8), or the Scipios (25.38.5-10; 38.58.4-6); the competitive spirit is so widespread in Rome that we can see it alive even in Roman women who contended with one another as well. Echoing Sallust in his presentation of a primitive virtuous Rome, Livy also depicts the female members of this past society as competing to surpass one another in virtue. Regarding the main qualities that Livy acknowledged in women, chastity appears top of the list and as the highest praise that the historian can bestow on a Roman woman. Competition in chastity [castitas] and modesty [pudicitia] appear very clearly in Book 10, around 295 BC, with the erection of the temple to Plebeian Modesty. ${ }^{7}$ The circumstances were as follows: a patrician woman who by marrying a plebeian had been denied entrance to the temple of Patrician Modesty, decided to set up a temple so that modest women among the plebeians could also participate in the ceremonies. During the dedication of the temple, she urged plebeian matrons to compete in modesty in the same way as their men competed in courage: "As the men of our state contend for the rewards of valor, so the matrons may vie for that of modesty [quod certamen virtutis viros in hac civitate tenet, hoc pudicitiae inter matronas sit]" (Livy, X, 23, 7, my emphasis). Pudicitia appears here as a womanly virtue worthy to be set up as an example and to foster competition with other women, analogous to the competition in bravery exercised by Roman men.

There was also competition and imitation in Livy's characters even in the most tragic events. In this case, it is not that the rivals try to outdo one another consciously, but the consequences of their actions bring about similar or comparable

7 - For the cult of Pudicitia, see LANGLANDS 2006, p. 4449. Cf. also CLARK 2007, esp. p. 39-46. 
results that acquire the resonances of a competition. The particular circumstances show that, once again, Livy chooses women to be at the centre of action in his records of early Rome. ${ }^{8}$ Not many years after the famous Lucretia had fought unsuccessfully for her honour and chastity - a fight that brought her nothing but disaster and an untimely death -, Verginia's tragic defence of her own maidenly modesty appears in the narrative and would end up having the same important political consequences for Rome which Lucretia's death had had:

This [Lucretia's death] was followed by a second atrocity, the result of brutal lust, which occurred in the City and led to consequences no less tragic than the outrage and death of Lucretia, which had brought about the expulsion of Tarquinus and the royal family. Not only was the end of the decemvirs the same as that of the kings, but the cause of their losing their power was the same in each case [Sequitur aliud in urbe nefas, ab libidine ortum, haud minus foedo eventu quam quod per stuprum caedemque Lucretiae urbe regnoque Tarquinios expulerat. Ut non finis solum idem decemviris qui regibus sed causa etiam eadem imperii amittendi esset] (Livy, III, 44, 1, my emphasis).

Even though the competition is less evident here than in the previous case of plebeian modesty, it is nevertheless clearly shown by the comparative haud minus (no less), which reflects the fact that the deaths of the two women are deliberately presented by the historian in explicit contrast with one another. Livy represents the deaths of Lucretia and Verginia competing with one another in the results. The competition in this instance ends up in a draw, which is reflected by the words idem and eadem: they not only have the same cause - the lust of the powerful, but also the same ending: the end of the monarchy in the first case, and the end of the decemvirate in the second one.

Advancing in time towards the Principate, the competition in which imperial Romans are immersed according to Tacitus not only has the characteristic darker tone of this historian, but it is also an 'inverted competition,' one which reflected the changed state of the city: verso civitatis statu. (Tacitus,
1 - All translations are from the latest Löeb editions with minor modifications, unless otherwise indicated.

2 - For exemplarity in Roman historiography, see esp. Chaplin 2000; Roller 2004; 2009; 2018. In a similar note, see Marincola 2010, p. 259-289. There is a vast bibliography on the relationship between rhetoric and ancient historiography, see for example, Wiseman 1979; Fornara 1983; Woodman 1984; Kraus; Woodman 1997; Marincola 2007. 
Annales I, 4, 1). According to Tacitus, and very much following Sallust's line of argument but for different reasons, ${ }^{9}$ Romans no longer competed in virtue, but in vice. Describing the panorama under the Principate, the historian comments that "the rivalry of the magnates and the greed of the officials had discredited the administration of the Senate and the People [suspecto senatus populique imperio ob certamina potentium et avaritiam magistratuum]" (Tacitus, Annales I, 2, 2, my emphasis). But, in Tacitus' opinion, the corruption and disorder were more widespread than previously, since it was not only men in important political posts who competed with one another in their desire for dominion and wealth, but also the soldiers, "who in former times competed in bravery and modesty contended now in insolence and insubordination [ut olim virtutis modestiaeque, tunc procacitatis et petulantiae certamen erat]" (Tacitus, Historiae III, 11, 2). As he does in the Annals for the period immediately after the death of Augustus, so he had done in the confused times of the civil wars in the Histories: he points out that both the civilians and the military had changed the contents and goals of their contests from virtue to vice. Another aspect that should not be overlooked here is that the competitive nature of Romans is presented as something 'natural', almost taken for granted: the reference to the past, ut olim, is there to stress a continuum regarding rivalry and emulation.

Before we move on to the next category of competition, it is important to be aware that in identifying internal competitions in historians it does not really matter if they present an idealized view of Rome in the past or generalize a situation that was not like that in reality - something that we cannot know for certain anyway - but what is of interest here is their insistence in presenting Rome as a 'field of competition' in their historical narratives. By portraying Romans constantly vying with each other, the historians show the dynamism of the Roman people, their drive not to conform to what had been achieved in the past, their desire to outdo their elders or, if that was not possible, at least to equal them. ${ }^{10}$ It is, of
9 - Tacitus does not explicitly blame the abundance of wealth and the lack of metus hostilis after the fall of Carthage as Sallust had done.

10 - On Roman aristocratic competition, see, for example, ROSENSTEIN 1990a; 1990b; 2006; ROLLER 2001; FARNEY 2007. 
course, difficult to know whether they were expressing reality as they actually saw it, or if they had perhaps a specific motive for presenting it like that, or both.

\section{External competition}

A second type of competition present in the historical narratives is the external one, which consists in the emulation that the historian is keen to foster between the contemporaries of his own generation and the historical characters or situations presented in the narrative. In this contest, one of the contenders belongs to the historical account and the other one is placed outside it, in the real world and at the actual time of the historian. As one of its practical uses, history had to be useful for the present: the time in which the historian was writing, then, was explicitly called to action by the records of the past, which "had a thriving, evolving, ideologically efficacious life in any given present" (ROLLER 2004, p. 51). Seeing history as a matter of contemporary relevance made both exempla and aemulatio something decidedly effective and necessary for one's own present.

We will again take Sallust as our first case. In both of his monographs he is constantly comparing the situation of Rome before and after the destruction of Carthage which is given as the turning point for the decline of the Roman Republic and the morality of its men. ${ }^{11}$ When Carthage, the rival of Rome's dominion, was finally destroyed in 146 BC, the lust first for money, then for power, grew upon them; and that was for Sallust the root of all evils:

For avarice destroyed honesty, integrity, and all other noble pursuits; taught in their place insolence, cruelty, to neglect the gods, to set a price on everything [Namque avaritia fidem, probitatem ceterasque artis bonas subvortit; pro his superbiam, crudelitatem, deos neglegere, omnia venalia habere edocuit] (Sallust, Bellum Catilinae X, 4).
11 - For the significance of the fall of Carthage as a turning point in Roman history see, for example, PURCELL 1995, p. 133-148. 
The deplorable race downhill had not stopped; on the contrary, in Sallust's own times it had reached an extreme point:

In the current degenerate state of society, however, who does not compete with his ancestors in wealth and extravagance, instead of in uprightness and energy? [At contra quis est omnium his moribus, quin divitiis et sumptibus, non probitate neque industria cum maioribus suis contendat?] (Sallust, Bellum Iugurthinum IV, 7, my emphasis). ${ }^{12}$

Sallust makes a bold accusation before his audience: his own contemporaries are engaged in a competition with the past as previous Romans had been, but they had missed the point: no longer do Romans try to outdo their elders in merit - cives cum civibus de virtute certabant -, but in material possessions. (Sallust, Bellum Catilinae IX, 2, my emphasis). The historian, however, will not remain passive before the dark panorama of his own times that he has presented, and under the auspices of historia as magistra vitae, he embarks on the task of moving his generation to change and spurring them to virtuous conduct in the same way as the traditional wax images of the ancestors inspired and inflamed younger generations of nobles:

I have often heard that Quintus Maximus, Publius Scipio, and other illustrious men of our state used to say that their hearts were inflamed by a burning desire to pursue virtue by the sight of their ancestors' portrait-masks [Nam saepe ego audivi $Q$. Maximum, P. Scipionem, praeterea civitatis nostrae praeclaros viros solitos ita dicere, cum maiorum imagines intuerentur, vehementissime sibi animum ad virtutem accendi] (Sallust, Bellum Iugurthinum IV, 5).

Of course it was not that the actual wax likeness had such power over them, continues Sallust, but that "the memory of great exploits kindled in the breasts of noble men a flame that cannot be put out until, by their own virtue, they attain the same glory and renown [sed memoria rerum gestarum eam flammam egregiis viris in pectore crescere neque prius sedari, quam virtus

12 - All the translations of the Bellum Iugurthinum are taken from COMBER; BALMACEDA 2009. 
eorum famam atque gloriam adaequaverit]" (Sallust, Bellum Iugurthinum IV, 5-6). This flame that Sallust is talking about, then, is the 'burning desire' of a young generation to excel the forefathers, or at least to equal them. Later on, he will even compare the use that his historical narrative - his memoria rerum gestarum - has on his audience precisely with the wax masks of the ancestors used in Roman funerals. ${ }^{13}$ Both material products of the past - the masks and the historical account fulfilled a similar aim: on the one hand, both publicized the virtue of the past, and on the other they awakened emulation for the present. Through this perception of the record of the past used as a reminder and beacon, history sought to influence the present and, to a certain extent, helped to shape it, as the reading of history inspired, should have inspired or, at least, was designed to inspire specific actions and behaviours.

In Livy's work too some implicit cases of competition with the present time of the historian appear scattered throughout the narrative, but it is in the preface where the idea of competitiveness between past and present is described very explicitly. In setting his goals for the project of giving an account of the history of Rome, Livy chose to give examples of virtue and vice as the key to understanding what the life and morals were like of the men who had made the Empire great: "quae vita, qui mores fuerint, per quos viros quibusque artibus domi militiaeque et partum et auctum imperium sit" (Livy, Praef. IX). He highlighted how the downfall came about little by little [paulatim], and above all, how weak was the response that his own generation was giving to the present circumstances:

with the gradual relaxation of discipline, morals first gave way, as it were, then sank lower and lower, and finally began the downward plunge which has brought us to the present time, when we can endure neither our vices nor their cure [labente deinde paulatim disciplina velut desidentes primo mores sequatur animo, deinde ut magis magisque lapsi sint, tum ire coeperint praecipites, donec ad haec tempora quibus nec vitia nostra nec remedia pati possumus perventum est] (Livy, Praef. IX, my emphasis).

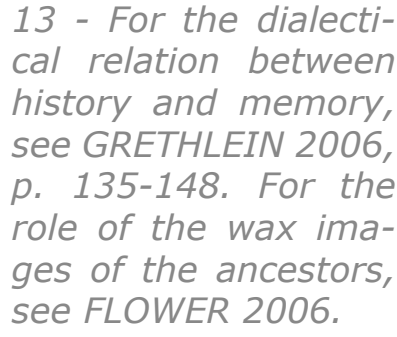

13 - For the dialectical relation between history and memory, see GRETHLEIN 2006 p. 135-148. For the role of the wax imasee FLOWER 2006. 
Livy had previously said that there had never existed any commonwealth greater in power, with a purer morality, or more fertile in good examples than Rome, but he then compares this picture with his own times. Deinde, paulatim, primo and tum are all adverbs that reinforce the sense of the evolution of Rome through time. The presence of donec (until) on the other hand, breaks this chain of progression and brings the reader ad haec tempora, that is, the historian's own times.

Beside these temporal markers that highlight the different layers of historical times and reinforce comparisons, there is another feature in Livy's preface that makes it particularly inviting to action in the present, and this is that the historian not only provides information about Rome's greatest men, their lives and their morals, but also addresses his audience directly in the second person singular. If one reads the preface one finds that he is unmistakably telling 'me' to 'do' something:

What chiefly makes the study of history wholesome and profitable is this, that you behold the lessons of every kind of experience set forth as on a conspicuous monument; from these you may choose for yourself and for your own state what to imitate, from these mark for avoidance what is shameful in the conception and shameful in the result [Hoc illud est praecipue in cognitione rerum salubre ac frugiferum, omnis te exempli documenta in inlustri posita monumento intueri; inde tibi tuaeque rei publicae quod imitere capias, inde foedum inceptu, foedum exitu, quod vites] (Livy, Praef. X). ${ }^{14}$

Livy had stated that history was useful and frugiferum, and so he urged his contemporaries to react to the present times - ad haec tempora - by choosing imitare or vitare the right examples from his long account of the history of Rome. And thus, by fostering emulation, his audience would be more prepared to make the effort to match or surpass their predecessors.

A less conspicuous case of promoting competition between the past and his own present in Livy is seen, once again, in his treatment of women's chastity. The care of this

14 - Cf. CHAPLIN 2015, p. 111 and for the preface in general MOLES 1993. 
virtue was also linked with politics in the cases of Vestal virgins being condemned for impudicitia. ${ }^{15}$ By their improper conduct - the violation of their Vestal vows was seen as nefas, similar to an act of pollution - they had put the state at risk (Livy, XXII, 57, 4). Livy may give these cases to provide exempla to the internal audience, that is, to other Vestals in his narrative, but also to the external one, namely, women in Augustan Rome. By the time of Livy's writing, Julia the Elder, Augustus' daughter, had already given cause of scandal with her behaviour and she received a harsh punishment from her father the Princeps. Was Augustus emulating Romans of old times in the chastisement of his daughter's lack of chastity? Or was Livy indirectly supporting the Princeps' so-called moral legislation? ${ }^{16}$ No doubt, the exile of Augustus' daughter (and later on grand-daughter as well) must have been something much talked about at that time, and the accounts in Livy of these chaste women giving their lives for the sake of pudicitia like Lucretia or Verginia, or the Vestals dying tragically when they had violated it, were probably seen as a warning. Moreover, Julia's punishment - being sent to a desert island - was metaphorically similar to the customary penalty for an unchaste Vestal virgin, namely, being buried alive. ${ }^{17}$ These comparisons with Livy's own times in Augustan Rome are no more than speculations, but the connections are nonetheless remarkable.

Tacitus, on the other hand, in one of his rare moments of being unequivocal, also spurs his contemporary readers to action and change. He is well aware that emulation and sound rivalry work as a trigger to improvement, and this is why he expresses his disappointment when he sees his own senatorial class mired in mediocrity and passivity. But, unlike Sallust this time, he does not idealize the past while overlooking the present, and is able to find good things in his own times under the Principate. One illustration of this is the example of parsimonia [sobriety, austerity] that Tacitus alludes to in Book 3 of the Annals. He explains that the excesses of wealth and luxury that Rome had undergone after the battle of Actium until the advent of the emperor Galba had been mitigated a little
15 - For cases of Vestal virgins condemned to death for unchastity, see 2.42 .11 ; 4.44.11; 8.15.7; 22.57.2; Per. $14 ; 20 ; 63$.

16 - On what has been termed Augustan moral legislation see, for example, FRANK 1975; BOUVRIE 1984; BADIAN 1985; GALINSKY 1996, passim, but esp. p. 128-140.

17 - Julia the Elder was exiled in $2 \mathrm{BC}$ to Pandateria in the Tyrrhenian Sea; Julia the Younger was exiled in $A D 8$ to Trimerus in the Adriatic. 
by the entrance of austere new men from the municipia and colonies, but that lately they had had an even greater promoter of parsimonia in Vespasian and his strict way of living. (Tacitus, Annales III, 55, 1-4)..$^{18}$ The historian comments that the desire to imitate the emperor did more than the fear of punishment to bring this ancient virtue of the maiores back into fashion. The desire to emulate Vespasian had proved more powerful than legal sanctions and deterrents (Tacitus, Annales III, 55, 4). This fact compels Tacitus to exclaim that not all past times were necessarily better:

Nor, indeed, were all things better in the old time before us; ${ }^{19}$ but our own age too has produced much in the sphere of true nobility and much in that of art which posterity well may imitate. In any case, may the honourable competition of our present with our past long remain! [nec omnia apud priores meliora, sed nostra quoque aetas multa laudis et artium imitanda posteris tulit. Verum haec nobis in maiores certamina ex honesto maneant] (Tacitus, Annales III, 55, 5, my emphasis). ${ }^{20}$

Competition between past and present is explicit here: Tacitus will not give up hope in his own generation and through 'positive reinforcement' he aims to move his contemporaries to reject the main vices of the Principate, namely inactivity, adulation and fear of the emperor. It has been argued that in his Annals Tacitus not only illustrates the sad condition of Romans under bad emperors, but also proposes a new model of behaviour for the good Roman (BALMACEDA 2017, p. 157-241), and thus, he is not a complete pessimist. Tacitus' nostra aetas, that is his present time under Trajan, is openly contending with the past and the historian is favourable to his own times. Competition is something that will continue; it is a characteristic feature of Roman culture: the notion that the present imitates the past and will be emulated by the future is consistent with Romans' attitude to the maiores.

\section{8 - For Vespasian's virtues, see LEVICK 1999, passim, but esp. p. 124-151. \\ 19 - One might assu- me this to be the be- lief of a Roman aris- tocrat.}

20 - See further GINSBURG 1993, p. 86-103. Cf. WOODMAN; MARTIN 2004, ad loc., esp. p. 408413. 


\section{Authorial competition}

A third type of competition present in the historical narratives of the Roman historians is the one that I have called authorial which involves the competitiveness proper to the author regarding his own occupation and work. This is the contest that the historian carries out with other historians as his own predecessors or 'ancestors' in writing history.

The most obvious example of this authorial competition is Livy, who declared bluntly:

Whether I am likely to accomplish anything worthy of the labour, if I record the achievements of the Roman people from the foundation of the city, I do not really know [Facturusne operae pretium sim si a primordio urbis res populi Romani perscripserim nec satis scio] ... perceiving as I do that the theme is not only old but hackneyed, through the constant succession of new historians, who believed either that in their facts they can produce more authentic information, or that in their style they will prove better than the rude attempts of the ancients... [quippe qui cum veterem tum volgatam esse rem videam, dum novi semper scriptores aut in rebus certius aliquid allaturos se aut scribendi arte rudem vetustatem superaturos credunt] (Livy, Praef. I-III, my emphasis).

The first sentence of $A b$ Urbe Condita could, of course, be interpreted just as the conventional captatio benevolentiae or words to win over the empathy of the reader to approach the work with benignitas. ${ }^{21}$ But the author is also telling us that emulation among writers of the history of Rome was something common: one after the other, Roman historians had written their histories hoping to supersede their predecessors either in content or style. The words certius (more authentic) and superaturos (surpass) show unambiguously that for Livy there was competition in this tradition of writers, as they hoped to provide more reliable information or write in a more refined style about Rome's past. Even though Livy does not have the traditional background of a retired politician who wrote history

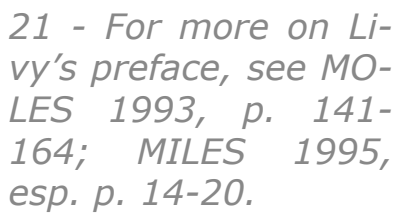

esp. p. 14-20. 
as the noblest occupation to which he could dedicate the rest of his life, he distinctively presents himself as one more link in that chain of competing historians (MARINCOLA 1997, p. 140). His rivals, in fact, were the previous republican annalists - of whom, unfortunately, we can only judge by their fragments such as Cincius Alimentus, Coelius Antipater or Cassius Hemina from the older generation and Claudius Quadrigarius (a major source from Livy's Book 6 onwards), Valerius Antias (frequently criticised for his exaggerations), Sempronius Asellio, Cornelius Sisenna or Licinius Macer. ${ }^{22}$ The result of Livy's efforts to supersede these annalists - his exceptional $A b$ Urbe Condita - makes us forget or at least disregard his lack of previous experience and credentials as a traditional Roman historian and, in comparison with his competitors, he earns a place very near the winners - if not as the winner - of the contest.

Tacitus also presents himself as part of this continuous succession of Roman historians. If Livy was explicit in saying that he was competing with his predecessors, he was diffident as to the results: "Whether... I do not know... [Facturusne... nec scio...]" (Livy, Praef. I). Tacitus, on the contrary, states clearly why he is better equipped than his previous colleagues to write history. With a few words he made the reader believe that he had no motives for being biased, and for that reason he persuaded his audience that his account of Roman history - specifically under the Principate - was more trustworthy than others. According to Tacitus, the histories of the emperors Tiberius, Caligula, Claudius, and Nero had been either falsified through terror when these emperors had been alive or written with hatred after their deaths. "Hence my purpose is," he continues, "to relate a few facts about Augustus - more particularly his last acts, then the reign of Tiberius, and all which follows, without either bitterness or partiality, from any motives to which I am far removed [sine ira et studio, quorum causas procul habeo]" (Tacitus, Annales I, 1, 3). Sine ira et studio appear at first sight to be the innocent words of an author's methodological programme, but they are in fact - among many other things Tacitus' powerful indication to his readers of his own superiority
22 - For the topic of Livy's sources, OAKLEY 1997, p. 13109 is essential. For the fragments of these Roman historians, see CORNELL 2013. 
(MARINCOLA 1997, p. 115, 144, 166). He had said it before in the Histories as well, when he stated that after the battle of Actium there were no historians who could write 'proper' history:

because they were ignorant of politics as being not any concern of theirs; later, because of their passionate desire to flatter; or again because of their hatred of their masters [primum inscitia rei publicae ut alienae, mox libidine adsentandi aut rursus odio adversus dominantis]. So, between the hostility of the one class and the servility of the other, posterity was disregarded [ita neutris cura posteritatis inter infensos vel obnoxios] (Tacitus, Historiae I, 1, 1).

According to Tacitus, the historians of the Republic had striven to do their job well, with eloquence and freedom [pari eloquentia ac libertati], but that had only lasted until "the interests of peace required that all power should be concentrated in the hands of one man [atque omnem potentiam ad unum conferri pacis interfuit]" (Tacitus, Historiae I, 1, 2).

Tacitus does not name his contemporary rivals in writing history, but one can infer at least two predecessors: Asinius Pollio and Velleius Paterculus. Even though Asinius Pollio (75 $B C$ - AD 4) cannot be counted as a contemporary to Tacitus and his historical works are mainly lost, we know that he provided much of the material found in Appian or Plutarch, and that his histories would have dealt with the times of the civil wars. ${ }^{23} \mathrm{~A}$ friend of Caesar and then Antony, he was not Augustus' enemy, but remained aloof from the vicissitudes of the new regime. He maintains the image of a "disillusioned republican" and "hostile to the emperor" (CORNELL 2013, p. 434), hence he could have written with ira or odio. Velleius, on the other hand, a former soldier serving directly under Tiberius' command and one who had benefited greatly by the new regime, wrote a very enthusiastic account about the second princeps, one with which Tacitus did not concur in the main, and to which he would not have hesitated to ascribe the aforementioned label of studium. ${ }^{24}$

\section{3 - Horace's Ode 2.1 gives this indication, $c f$. WOODMAN 2003, p. 191-216. For more on Asinius Pollio, see FrHist I, p. 430-445 (CORNELL 2013).}

24 - For Velleius' career and historical work, see respectively LEVICK 2011; RICH 2011. For Velleius' view of Tiberius' virtues, see for example, SCHMITZER 2011; BALMACEDA 2014. 
Sallust's contest is slightly different. He compares himself not with previous or contemporary historians, but with politicians and men of action. His challenge is not simply to produce a more powerful narrative or a more truthful historical account than previous historians. He competes against the very doers of the actions he is telling the reader about:

It is glorious to serve one's own country by deeds, even to serve her by words is a thing not to be despised; one may become famous in peace as well as in war [Pulchrum est bene facere rei publicae, etiam bene dicere haud absurdum est; vel pace vel bello clarum fieri licet]. Not only those who have acted, but also those who have recorded the acts of others often receive our approbation [et qui fecere et qui facta aliorum scripsere, multi laudantur] (Sallust, Bellum Catilinae III, 1).

Sallust broadens the fields by which Romans could achieve glory in Roman society: the customary competition for activities such as public office or the waging of wars was going to be expanded to other occupations too, such as the writing of history. Sallust's reflection on his own career provides us with one of the earliest references to the glory and fame that belong to the historian, which are based mainly on surmounting the difficulties attached to writing about the past. ${ }^{25}$ "I regard the writing of history as one of the most difficult tasks, because the style and diction must be equal to the deeds recorded [tamen in primis arduum videtur res gestas scribere: primum, quod facta dictis exaequanda sunt]" (Sallust, Bellum Catilinae III, 2, my emphasis). The other difficulty was that the historian needed some courage to overcome and put up with malicious reproaches:

because such criticisms as you make of others' shortcomings are thought by most men to be due to malice and envy [dehinc, quia plerique, quae delicta reprehenderis, malevolentia et invidia dicta putant]. Furthermore when you commemorate the distinguished virtue and fame of good men, while everyone is quite ready to believe you when you tell of things which he thinks he could easily do himself, everything beyond that he regards as fictitious, if not false [ubi de magna virtute atque gloria bonorum memores

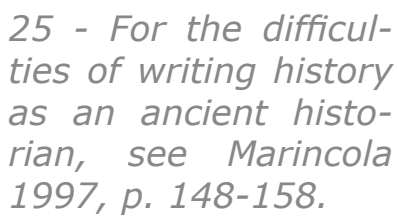

1997, p. 148-158. 
quae sibi quisque facilia factu putat, aequo animo accipit, supra ea veluti ficta pro falsis ducit] (Sallust, Bellum Catilinae III, 2).

By this explicit association of facta et dicta - deeds and words - Sallust is presenting himself as a man of action, comparable to the actors of his own history, perhaps not shown in military campaigns or public office - although he was involved in both but through recording the memory of the things done: memoria rerum gestarum. He states that his writings, which could be seen by some as a simple pastime for a retired politician will, in fact, be more useful than others' actions: "greater benefit to the state is likely to come from my retirement than from others' activity [maiusque commodum ex otio meo quam ex aliorum negotiis rei publicae venturum]" (Sallust, Bellum Iugurthinum IV , 4, my emphasis). And indeed, this proved to be the case, because Sallust's monographs provided a rich example for historical writing henceforward, and were useful in many more ways than the historian could have foreseen.

How can Sallust compare actual deeds and achievements in history with the written account of these same achievements - which of course are not really comparable? The answer is that he emphasises the similar nature of the difficulties that have to be overcome in both cases: the two situations present parallel intrinsic and extrinsic challenges. On the one hand, there is the intrinsic challenge of doing something remarkable either in politics or in war, and there is also some intrinsic value in writing about it 'properly', matching deeds with words, doing justice to great actions by writing about them in great words. The extrinsic challenge, on the other hand, is more related to an external problem, that is, what others might think of the actor involved in political action - or warfare - or of the historian himself. Both are open to praise or criticism and to the relentless judgement of both their colleagues and posterity. ${ }^{26}$

Authorial competition, therefore, could involve two types of competitiveness among historians: the first one - seen with Livy and Tacitus - was the historian rivalling his own colleagues, 
as if he were contending with his own maiores, in some way following their exemplum, but trying to supersede them. The second and more ambitious type, implied that the historian saw himself as crucial and essential as the characters in his historical narrative because the way and manner in which the historical facts were told - and therefore understood - were as important as the facts themselves.

\section{Final Considerations}

Competition went hand in hand with exemplarity in Roman historiography, or rather, the historians fostered rivalry and emulation precisely by providing historical examples. The power of exemplarity in Roman historiography, then, was used by the historians not only as a pedagogical rhetorical device to explain or illustrate the situation that was being narrated, but also as an exhortative encouragement to motivate readers into action.

It is interesting to see how the historians in the first place present exempla and competition in virtues to the internal audience of their narratives - that is to other characters in the historical account - as if to show in a practical way to the external audience - i.e., their own contemporaries - how they should read the history of their own past and what they should do to match their ancestors. The internal competition among the historical characters appears at first sight a rather subtle way of promoting rivalry with the present, since it requires an alert audience, but it is nonetheless inspiring and powerful. External competition, by contrast, involves addressing the reader in terms that may be more or less aggressive depending on the historian, and the message is made clearer. The explicit educational function of history was precisely placed in this message; the Roman historian had to do more than merely tell pleasant stories from the past: he had to pass moral judgement. For Tacitus, for example, this was history's highest function [praecipuum munus annalium]: "to ensure that virtue shall not lack its record and to hold before the vicious word and deed the terrors of posterity and infamy" (Tacitus, Annales III, 65, 1)..$^{27}$

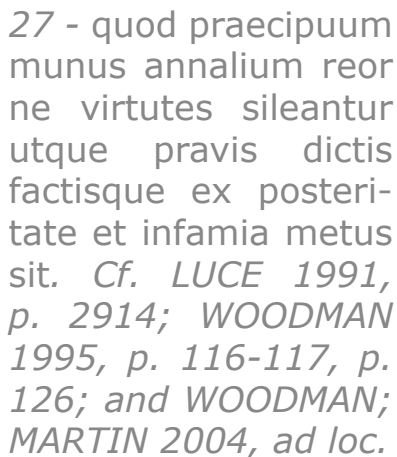
MARTIN 2004, ad loc. 
History was a commemoration of virtue, and a deterrent from following bad examples lest one's evil deeds should be recorded for ever. As magistra vitae history had to teach lessons to the reader and this was done by giving examples, persuading the audience and fostering action by emulation.

Authorial competition, more or less explicit depending on each author, in some way showed what the historians thought about themselves and the position and place they occupied in the development of their craft. Often their deepest thoughts on the nature of their occupation were crystallised within the discussion of the purpose of writing history or while they were trying to justify their reasons for embarking on this activity after so many had already done the same. In this way, the historians not only promoted competition with their writings, but they actually set an example of how the competition should be undertaken. The presence of competing narratives, competing characters and competing authors reveal the competitive way in which Romans approached all things.

In a society in which action and achievement were the main measurements of personal success and in a culture where the mores maiorum played a major role, historical exempla presented as a challenge for the present had a great appeal to contemporary audience. Roman historians, then, were not mere passive chroniclers of past times. To a certain extent, they became active guides of conduct to Roman society by promoting a specific moral code of values. Reading history was seen as something eminently useful and applicable. It was there to inspire the reader to think: 'I will do the same' or 'I can do better'. Much more explicitly than in our contemporary age, to influence the present constituted a primary aim in historical writing in antiquity. Competition in Roman historiography internal, external or authorial - acted as a powerful incentive to trigger action in the present, making the records of historical past something decidedly practical.

Competition between past and present constituted the core of the exemplary function of history in Rome. 
ARIETI, James. Rape and Livy's view of Roman History. In: DEACY, Susan; PIERCE, Karen. Rape in Antiquity. London: Bristol Classical Press, 1997, p. 209-229.

BADIAN, Ernst. A Phantom Marriage Law. Philologus, v. 129, p. 82-98, 1985.

BALMACEDA, Catalina.The Virtues of Tiberius in Velleius' Histories. Historia, v. 63, n. 3, p. 340-363, 2014.

. Virtus Romana: Politics and Morality in the Roman Historians. Chapel Hill. University of North Carolina Press. 2017.

BATSTONE, William. The Antithesis of Virtue: Sallust's Syncrisis and the Crisis of the Late Republic. Classical Antiquity, v. 7, n. 1, p. 1-29, 1988.

BOUVRIE, Synnve. Augustus' Legislation on Morals which morals and what aims? Symbolae Osloenses, v. 59, p. 93-113, 1984.

BRUNO, Luigi. Crimen, regni e superbia in Tito Livio. Giornale Italiano di Filologia v. 19, p. 236-259, 1966.

CHAPLIN, Jane. Livy's Exemplary History. Oxford, Oxford University Press, 2000. . Livy's Use of Exempla. In: MINEO, Bernard. A Companion to Livy. Malden and Oxford: Wiley-Blackwell, 2015, p. 102-112.

CLAASSEN, Jo-Marie. The Familiar Other: the pivotal role of women in Livy's narrative of political development in early Rome. Acta Classica, v. 41, p. 71-103, 1988. 
CLARK, Anna. Divine Qualities, Cult and Community in

Republican Rome. Oxford: Oxford University Press, 2007.

COMBER, Michael; BALMACEDA, Catalina. (eds.). Sallust: The War Against Jugurtha. Oxford: Liverpool University Press, 2009.

CORNELL, Tim. (ed.). The Fragments of the Roman Historians. Oxford: Oxford University Press, 2013.

FARNEY, Gary. Ethnic Identity and Aristocratic Competition in Republican Rome. Cambridge: Cambridge University Press, 2007.

FELDHERR, Andrew. Spectacle and Society in Livy's History. Berkeley and Los Angeles: University of California Press. 1998.

FLOWER, Harriet. Ancestor Masks and Aristocratic Power in Roman Culture. Oxford: Oxford University Press, 2006.

FORNARA, Charles. The Nature of History in Greece and Rome. Berkeley and Los Angeles: University of California Press, 1983.

FRANK, Richard. Augustus' Legislation on Marriage and Children. Classical Antiquity, v. 8, p. 41-52, 1975.

GALINSKY, Karl. Augustan Culture. Princeton: Princeton University Press, 1996.

GINSBURG, Judith. In Maiores Certamina: Past and Present in the Annals. In: LUCE, James; WOODMAN, Anthony John. Tacitus and the Tacitean tradition. Princeton: Princeton University Press, 1993, p. 86-103.

GRETHLEIN, Jonas. Nam Quid Ea Memorem: The Dialectical Relation of the Res Gestae and Memoria Rerum Gestarum in Sallust's Bellum Jugurthinum. The Classical Quarterly, v. 56, n. 1 , p. $135-148,2006$. 
HABERMAN, Lidia. Nefas an libidine ortum: Sexual Morality and Politics in the Early Books of Livy. Classical Bulletin, v. 57, p. $8-11,1980$.

HALLET, Judith. Women as Same and Other in the Classical Roman Elite. Helios, v. 16, p. 59-78, 1989.

HARDIE, Philip. Epic Successors of Virgil. Cambridge: Cambridge University Press, 1993.

HÖLKESKAMP, Karl-Joachim. Exempla und Mos Maiorum. Überlegungen zum kollektiven Gedächtnis der Nobilität. In: HÖLKESKAMP, Karl-Joachim. Senatus Populusque Romanus. Münich: Steiner Verlag, 2004, p. 169-198.

JOPLIN, Patricia Klindienst. Ritual Work on Human Flesh: Livy's Lucretia and the rape of the body politic. Helios, v. 17 , n. 1, p. 51-70, 1990.

JOSHEL, Sandra. The body female and the body politic: Livy's Lucretia and Verginia. In: RICHLIN, Amy. Pornography and Representation in Greece and Rome. Oxford: Oxford University Press, 1992, p. 112-130.

KAPUST, Daniel. Republicanism, Rhetoric, and Roman Political Thought. Sallust, Livy and Tacitus. Cambridge: Cambridge University Press. 2011.

KRAUS, Christina; WOODMAN, Anthony John. Latin Historians. Oxford. Oxford University Press. 1997.

LANGLANDS, Rebecca. Sexual Morality in Ancient Rome. Cambridge: Cambridge University Press. 2006.

LEVICK, Barbara. Vespasian. London and New York: Routledge, 1999.

- Velleius Paterculus as senator: a dream with footnotes. In: COWAN, Eleanor. Velleius Paterculus: Making History. Swansea: Classical Press of Wales, 2011, p. 1-16. 
LUCE, Timothy Joseph. Tacitus on History's Highest Function, ANRW, v. II, n. 33.4, 2904-2927, 1991.

MARINCOLA, John. Authority and Tradition in Ancient Historiography. Cambridge: Cambridge University Press. 1997

A Companion to Greek and Roman Historiography. Malden and Oxford: Wiley-Blackwell. 2007.

. The Rhetoric of History: Allusion, Intertextuality, and Exemplarity in Historiographical Speeches. In: PAUSCH, Dennis. Stimmen der Geschichte: Funktionen von Reden in der antiken Historiographie. Berlin and New York: De Gruyter, 2010, p. 259-289.

MILES, Gary. Livy: Reconstructing Early Rome. Ithaca: Cornell University Press, 1995.

MOLES, John. Livy's Preface. Papers of the Cambridge Philological Society, v. 39, p. 141-168, 1993.

MOORE, Timothy. Morality, history and Livy's wronged women. Eranos, v. 91, p. 38-46, 1993.

OAKLEY, Stephen. A Commentary on Livy Books VI to X. Volume 1: Introduction and Book VI. Oxford: Oxford University Press, 1997.

PAUL, George. A Historical Commentary on Sallust's Bellum Iugurthinum. Trowbridge: Francis Cairns, 1984.

PURCELL, Nicholas. On the Sacking of Carthage and Corinth. In: INNES, Doreen; HINE, Harry; PELLING, Christopher. Ethics and Rhetoric. Oxford: Oxford University Press, 1995, p. $133-148$.

RICH, John. Velleius' History: genre and purpose. In: COWAN, Eleanor. Velleius Paterculus: Making History. Swansea: Classical Press of Wales, 2011, p. 73-92. 
ROLLER, Matthew. Constructing Autocracy. Aristocrats and Emperors in Julio-Claudia Rome. Princeton: Princeton University Press, 2001.

. Exemplarity in Roman culture: the cases of Horatius Cocles and Cloelia. Classical Philology, v. 99, n. 1, p. 1-56, 2004.

. The exemplary past in Roman historiography and culture. In: FELDHERR, Andrew. The Cambridge Companion to the Roman Historians. Cambridge: Cambridge University Press, 2009, p. 214-230.

Models from the Past in Roman Culture. A World of Exempla. Cambridge: Cambridge University Press, 2018.

ROSENSTEIN, Nathan. War, Failure, and Aristocratic Competition. Classical Philology, v. 85, no. 4, 255-265, 1990a.

- Imperatores Victi: Military Defeat and Aristocratic Competition in the Middle and Late Republic. Berkeley and Los Angeles: University of California Press, 1990b.

Aristocratic Values. In: ROSENSTEIN, Nathan; MORSTEIN-MARX, Robert. A Companion to the Roman Republic. Malden and Oxford: Wiley-Blackwell, 2006, p. 365-382.

SCHMITZER, Ulrich. Roman Values in Velleius. In: COWAN, Eleanor. Velleius Paterculus: Making History. Swansea: Classical Press of Wales, 2011, p. 73-92.

SKLENÁR, R. La République des Signes: Caesar, Cato, and the Language of Sallustian Morality. Transactions of the American Philological Association, v. 128, p. 205-220. 1998.

STEVENSON, Tom. Women of Early Rome as Exempla in Livy. Ramus, v. 29, p. 175-189, 2000. 
WALTER, Uwe. Memoria und res publica: zur Geschichtskultur im republikanischen Rom. Berlin: Verlag Antike, 2004.

WISEMAN, Peter Timothy. Clio's Cosmetics. Leicester: Leicester University Press. 1979.

WOODMAN, Anthony John. Rhetoric in Classical Historiography. London and Sydney: Croom Helm. 1984.

Praecipuum Munus Annalium. Museum Helveticum, v. 52, p. 111-126, 1995.

. Poems to Historians. Catullus 1 and Horace, Odes 2.1. In: BRAUND, David; GILL, Christopher. Myth, History and Culture in Republican Rome, Studies in Honour of T.P. Wiseman. Exeter: University of Exeter Press, 191-216, 2003.

WOODMAN, Anthony John; MARTIN, Ronald. (eds.). The Annals of Tacitus Book 3. Cambridge: Cambridge University Press. 2004.

\section{AGRADECIMENTOS E INFORMAÇŌES}

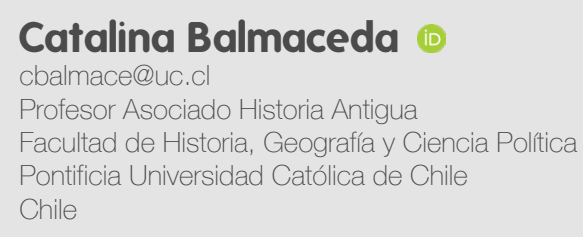

This article is part of the project funded by Fondecyt 1160272 . 